\title{
Effect of Thermal Radiation on Viability of Cassava Plant Population Cultivated Around Flare Site in the Niger Delta Region of Nigeria
}

\author{
Oyet, G.I ${ }^{1}$, Achinewhu S.C ${ }^{2}$, Sigalo, F.B ${ }^{3}$, Audu P. ${ }^{4}$ \\ ${ }^{1,4}$ Environment Health Safety Security and Quality Department, Oando Marketing Plc, Apapa Lagos. \\ ${ }^{2}$ Department of Food Science and Technology, Rivers State University of Science and Technology, P.M.B 5080, \\ Port Harcourt. Nigeria. \\ ${ }^{3}$ Department of Physics, Rivers State University of Science and Technology, P.M.B 5080, Port Harcourt. \\ Nigeria
}

\begin{abstract}
Three improved variety of cassava cultivars (NR-8082, NR-8429, and TMS-30572) grown within 2 $\mathrm{km}$ flare distance were studied for their viability, yield and tolerance level to flare radiation in Rumuekpe flow station of Rivers State. The plots were designed according to distances: 0-150m, 150-300m, 300-450m, 450$600 \mathrm{~m}$ and 1000-2000m. Randomized complete block design (RCBD) with three (3) treatments in five replications was used. Heat radiation was measured with a pyranometer equipped with an automatic logging system. Flare quality was measured with a British standard miniature smoke chart: The smoke chart BS $2742 \mathrm{~m}$ was used at a distance of $18.5 \mathrm{~m}(60 \mathrm{ft})$. The number of viable and dead cassava plants was counted and the percentage viability/loss calculated and analysed for 1 month and 10 months of age planting period respectively.. The statistical differences were analyzed by analysis of variance and least significant difference. The studies showed that at $0-150 \mathrm{~m}\left(603.84 \pm 5.76 \mathrm{w} / \mathrm{m}^{2}\right)$ for (TMS 30572) was $2 \%$ and $405 \%$, (NR -84292) was $15 \%$ and $50 \%$ losses at 1 month and 10 months growth period, at $150-300 \mathrm{~m}\left(588.40 \pm 4.0 \mathrm{w} / \mathrm{m}^{2}\right)$ for $(\mathrm{NR}$ $84292)$ was $12 \%$ and $31 \%,($ TMS-30572) $4 \%$ and $20 \%$ losses under the same period. The control 1000-2000m $\left(428.83 \pm 0.79 \mathrm{w} / \mathrm{m}^{2}\right)$ shows a population loss of 5\% for NR- 84292 and $2 \%$ loss for NR- 8082 and TMS-30572 after one month of age. At Ten (10) months of planting period, the effect of thermal radiation on viability was evident (25\%-50\%) population loss with severity in NR-84292 at 0-150m, while from 450-2000m flaring distance, the plants showed 100 percentage viability at the ten month growth period. The number of tubers ranged from 1-5 at 0-150m and 10-16 at 1000-2000m flare distance respectively. Flare quality measurement, showed a compliance, and non-compliance level of $77.98 \%$ and $22.02 \%$ of light transmission through smoke and smoke transmission through light respectively using the DPR limits. The study further demonstrated that the high degree of population loss (50\%) associated with cultivar NR-84292 after Ten months at 0-150m could be attributed to low tolerance of the cultivar to excessive thermal radiation. NR- 8082 and TMS-30572 could be said to have a high degree of tolerance to heat and other environmental stress, as shown in the $2 \%$ loss at 0 $150 \mathrm{~m}$ and 1000-2000m flare distance respectively. The implications of gas flare on cassava production by farmers in the region were addressed.
\end{abstract}

Keywords: Cassava (Manihot esculenta), flare distance, tolerance, viability, yield and thermal radiation.

\section{Introduction}

Air pollution arising from oil production could be viewed from chemical, odour, visual and thermal pollution. Until recently with the introduction of Associated and Non- Associated gas plants, Liquefied natural gas plants, in Nigeria, almost ninety percent of gas discovered by Oil companies in the process of crude oil exploitation is flared. In the case of plant upsets, thermal radiation effects can be serious and damaging if flare height and distance from personnel and buildings is not adequate, Ogoni Issue (1996). Also, according to this report, another local effect is caused when the thermal energy released from the process units increases the average temperature in the vicinity of the refinery and contributes to localized climate changes. Oil companies continue to flare gas in Nigeria despite legal opposition for varieties of reasons. First, it was said that when most oil facilities were built in Nigeria, there were no significant market for Nigeria gas nationally and internationally and no system was built to collect associated and non -associated gas produced along with the oil, as a byproduct. Second, there is limited demand for gas by both industrial and domestic consumers partially because of low domestic oil prices which make gas an unattractive energy source to develop given the high cost of collection and treatment (Ogoni Issue, 1996).

The earth is our home, but man's quest for survival has tremendously affected and altered its true existence and God's architectural work. It is only recently that man became aware of the danger caused to the environment, mostly due to the cries of the ecologist and man's observation of the damage caused to the 
ecosystem and especially the food chain on which humanity is completely dependent for life. Thermal radiation over the years are known to cause growth reduction, defined as reduction in the growth of the organism as well as reduced seed germination, abnormalities, or reduction in viability of offspring's Miller, 2015. Also, according to Ryan 2012, thermal radiation resulted in direct burn damage to exposed tissue

Many studies have been carried out on different aspects of environmental pollution in the country, but not very much appears to have been done in the area of thermal (heat) radiation. Yet, thermal radiation remains one very important pollutant of the environment. The sources of heat radiation in a typical oil or gas industry includes flares, flames, combustible engines (compressor) and sparks (Sigalo, 1997.)

Accordingly, a closer look at the geographical spread of oil fields would show that the flares are located principally in the South-Eastern axis of the Nigeria Delta Zone (mainly Delta / Bayelsa / Rivers / Imo / Akwa Ibom States), where also there is (or will be) a preponderance of large chemical process plants, such as existing two oil refineries, steel plant, fertilizer complex, petrochemical plant as well as the Nigeria liquidfied natural gas (NLNG) complex. All of these categories of plants have stacks for waste-gases or carry-over gas. When this scenario is superimposed on the oil-field flares, there is a veritable potential for acid rain" disasters, in this industrial belt of Nigeria. (Avwiri and Ebeniro, 1994)

For the purpose of this study, the main radiation is the flare. Thus, gas flaring as one of the processes of resource exploitation could be defined as a controlled disposal of surplus combustible vapours by igniting them in the atmosphere. (Nature Conservation report, 1986).

Heat radiation is a process of propagation of the internal energy of an emitting substance, be it solid, liquid or gas, through electromagnetic waves. Electromagnetic wave is a kind of heat energy transmitted by waves propagating with the speed of light, equal to $3 \times 10^{8} \mathrm{~m} / \mathrm{sec}$ (Yuan and Zeng 1985).

Nigeria is one of the major petroleum producers in the world. It flares an average of 22 billion cubic meters of gas annually as a by-product of petroleum exploitation. This practice is inimical both to the environment and a waste to the economy. According to Ede and Johnson (2000) there were over 300 flare sites in the country and when heat radiation was measured at 10 stations and converted into other energy equivalents for the flared gas it was observed that the flared gas was greater than the total electric power generated in the country for any given period even at 30 percent fuel conversion. Nigeria is reported to flare more gas than any other country in the world. The incidence of gas flaring has been going on since 1957 when commercial petroleum production began.

Flaring of produced gas is the most significant source of air emissions; particularly where there is no infrastructure or market available for the gas. However, where viable gas is processed and distributed as an important commodity, through integrated development and providing markets for all products, the need for flaring will be greatly reduced (NLNG project in Bonny and Liquid Gas plant in Soku (LGSP). Flaring may also occur on occasions as a safety measure, during start-up, maintenance or upset in the normal processing operation.

Nigeria's gas reserves exceed the foreseeable needs of domestic, regional and international markets for gas (SPDC, 2001).

The gas is in two forms. Associated gas (AG), which is either dissolved in and is voluntarily produced with oil, or lying on top of oil in a combined oil and gas reservoir. The other is Non-associated gas (NAG), which comes from reservoirs containing gas only. On the average, about 1000 standard cubic feet (SCF) of gas is produced in Nigeria with every barrel of oil. Therefore, with oil production of some 2.2 millions barrels per day about 2.2 billion scf of associated gas is produced every day and much of this is being flared. (SPDC, 2001).

A large proportion of gas flared for instance in the Niger Delta of Nigeria is vented as methane, which goes to show how many tons of this substance is released into the atmosphere per year. Increased temperature in gas flared areas ranges from $1300-1400^{\circ} \mathrm{C}$ (Idoniboye, 1998). This is considered very high for both plant and animal life, because they contain sulphides, carbonates and nitrates, resulting as Hydrogen Sulphides, $\left(\mathrm{H}_{2} \mathrm{~S}\right)$, Sulphur-dioxide $\left(\mathrm{SO}_{2}\right)$, Carbon Monoxide (CO), Nitrogen Dioxide $\left(\mathrm{NO}_{2}\right)$, etc. which may be involved due to the atmosphere of the flaring environment and are carried away many kilometers depending on wind speed and direction. This causes some physiological changes in certain vegetation most likely leading to death. Some of the effects most probably on plants are internodes shortening of apical internodes, leaf distortion, and discoloration, crinkling, and pebbling, reduction in leaf size as well as in chlorophyll contents due to oxygen deficiency and gas toxicity in the environment (Idoniboye, 1998).

Similarly, gas flare is usually viewed as the effect of light intensity and temperature on the environment. Natural gas flares are thought to cause varying degrees of pollution. The magnitude of these effects to the micro meteorological, biological, chemical parameters and soil conditions in the environment have not been adequately documented (Okezie \& Okeke, 1987). Local farmers have complained about retardation of growth and productivity of farm crops around gas flares. Isichei and Sandford (1970) observed depression in flowering and fruiting in Chromolaena odorata. 
Oluwatimilehin (1981)observed similar results in okra and palm trees; and in cassava; he found that the tubers decreased in length and weight with decreasing distance from the gas flares.

A typical gas flare in a Nigeria flow station is usually located at ground level, and is surrounded by thick vegetation and farmlands, with the village huts and human inhabitants located from about 20 - 300 meters from the heat-source or flare (Egbuna 1987). Viewed against international environmental standards, this is a very hazardous and unacceptable situation. The thermo-chemistry of gas combustion (Perry and Chilton 1973) shows that the heat radiation from a flame is due principally to the radiation from suspended particles of microscopic dimensions (such as ash, coal particles, water vapour etc). In the hot gaseous combustion products the contribution to radiation from the chemical combustion process itself. (i.e. chemiluminescence) is relatively negligible. Furthermore, the radiation level for a gas flare is also a function of the flame temperature, gas flowrate, and flare-stack geometrical design.

Some of the Multi-Nationals oil companies are, however committed to stopping routine flaring by 2008 through conserving, re-injecting, gathering and harnessing the gas via the use of gas compressors and Liquefied Gas plants. (SPDC, 2001). In responding to flare out, Shell took a giant step to commissioning of AGG compressors in most of the swamp/land locations, in addition to gas plants in Obigbo, Belema, Alakiri, Soku etc. Also, most of the companies are working to ensure cleaner burning flares with aspirated tips; boskel flare tips and Free-liquid knock out pots.

\section{Materials And Methods}

The experimental plots were sited on an agro-ecological zone. The coastal plain sands - Rumuekpe flow station of Shell Petroleum Development Company Nigeria Limited (SPDC) Port Harcourt. Rumuekpe flow station is located in Emuoha Local Government Area of Rivers State, which is on a mid-point coordinate of Latitude $4^{\circ} 58^{\prime} 49^{\prime \prime} \mathrm{N}$ and Longitude $6^{\circ} 41^{\prime} 15^{\prime \prime} \mathrm{E}$ via mid-belt of $469571 \mathrm{EE}$, and $108624 \mathrm{MN}$. (DTE-GEM 2001).

Rumuekpe is a humid tropical area. The rainfall pattern is bimodal with peaks in June and September, and the period of low precipitation in August. The long rainy season is between April and early August, while the short rainy season is between late August and October. The dry season is from November to March interrupted occasionally by sporadic down pour. Rumuekpe, like Port Harcourt within latitude $04^{0} 5^{1}$ and longitude $07^{0} 01^{1} \mathrm{E}$ (FAO, 1994) has an annual rainfall of between $2000 \mathrm{~mm}$ and $2453 \mathrm{~mm}$, while the annual temperature is between $22.6^{\circ} \mathrm{C}$ and $31.2^{\circ} \mathrm{C}$ (RISADP, 1991). The experiment was conducted for a period of 12 months:

Three exotic cultivars used for the experiment were obtained from the National Root Crop Research Institute (NRCRI) Umudike, Abia state and International Institute of Tropical Agriculture (IITA), Onne substation.

These were:

TMS -30572

NR -8082

NR -84292

\section{Experimental design}

A randomised complete block design (RCBD) with three (3) treatments in five replications was used. The plots were designed according to distance: $0-150 \mathrm{~m}, 150-300 \mathrm{~m}, 300-450 \mathrm{~m}, 450-600 \mathrm{~m}$ and 1000-2000m. All the experimental plots were in the downward direction. Control plot was located at a distance of $2000 \mathrm{~m}$ (Elele Road) near well 4 approximately $2 \mathrm{~km}$ - North West of the flare downwind direction, as contained in Table 1.

Table 1.1: Layout of the experimental plots- Land preparation and planting

\begin{tabular}{|l|l|l|l|l|}
\hline $0-150 \mathrm{~m}$ & $150-300 \mathrm{~m}$ & $300-450 \mathrm{~m}$ & $450-600 \mathrm{~m}$ & $1000-2000 \mathrm{~m}$ \\
\hline NR -8082 & NR -8082 & NR -8082 & NR -8082 & NR -8082 \\
\hline TMS- 30572 & TMS -30572 & TMS -30572 & TMS -30572 & TMS -30572 \\
\hline NR -84292 & NR -84292 & NR -84292 & NR -84292 & NR -84292 \\
\hline
\end{tabular}

\section{Thermal radiation:}

Heat radiation was measured with a pyranometer equipped with an automatic logging system. The sensor was focused towards the direction of flare for Ten minutes interval to record radiation every ten seconds interval. The mean reading taken over the ten minutes for a period of $1 \mathrm{hr}$ (one hour) exposure time was then recorded as the thermal radiation value at $0-150 \mathrm{~m}$ and this was done for the $2 \mathrm{~km}$ farm layout.

The statistical differences were analysed by analysis of variance and least significant difference as described by Wahua ( 1999). 


\section{Flare Quality Measurement:}

Flare quality was measured by the method proposed by EGASPIN (2002). Under luminescence, the visual flare quality as a means for evaluating the combustion efficiency was measured with a British standard miniature smoke chart: The smoke chart BS $2742 \mathrm{~m}$ was used at a distance of $18.5 \mathrm{~m}$ (60 feet) from the bound wall. The chart was used under daylight conditions where there was minimal or no haze. It was held at arm's length and the colour of the smoke was then compared with the chart colour scale rated $0-4$. The closest quality was then taken and recorded as the flare quality EGASPIN (2002).

\section{Cassava plant viability}

The number of viable and dead cassava plants was counted and the percentage viability/loss calculated.

Calculation

No of Viable cassava plant (V)

No of Dead cassava plant $(L)$

Total Cassava plant population

Percentage Viability (V)estimated as

Percentage loss (L)estimated as

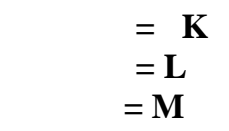

$==\mathrm{K} / \mathrm{M} X 100 / 1$.

$=\mathrm{L} / \mathrm{M} \mathrm{X} \mathrm{100/1}$

\section{Plant height:}

The height of plant was measured using a rope, which was then measured on a meter rule.

\section{Tuber number and weight per stand/ weight of Peeled Tuber:}

The number of tuber per stand was estimated by physical counting of the tubers, while tuber weight per stand was measured using the processing weighing balance. (Lever Balance) and the mean value from three stands (mounds) per cultivar recorded. The same process carried out for the peeled tubers

\section{Results And Discussions}

The results of the effect of thermal radiation on cassava plant population loss/viability and that of Rumuekpe flare quality measurement are as shown in table 2.1 and table 2.2 respectively.

Also, the figures are as follows:

Table 2.1: Effect of thermal radiation on cassava plant population loss /viability

\begin{tabular}{|c|c|c|c|c|c|c|c|}
\hline $\begin{array}{l}\text { Flare } \\
\text { distance } \\
\text { (m) }\end{array}$ & Cultivars & $\begin{array}{l}\text { Thermal radiation } \\
\left(\mathrm{w} / \mathrm{m}^{2}\right) \\
\text { Mean } \pm \text { SEM }\end{array}$ & $\begin{array}{l}\text { One } \\
\text { month of } \\
\text { age }\end{array}$ & $\begin{array}{l}\text { Ten } \\
\text { months } \\
\text { of age }\end{array}$ & $\begin{array}{l}\text { No of tubers stand } \\
\text { at Harvest } \\
\text { Mean } \pm \text { SEM }\end{array}$ & $\begin{array}{l}\text { Weight of tubers } \\
(\mathrm{kg}) \text { at Harvest } \\
\text { Mean } \pm \text { SEM }\end{array}$ & $\begin{array}{l}\text { Plant height }(\mathrm{cm}) \\
\text { at Harvest } \\
\text { Mean } \pm \text { SEM }\end{array}$ \\
\hline \multirow[t]{3}{*}{$0-150$} & NR-8082 & $603.84 \pm 5.76^{\mathrm{a}}$ & $7 \%(\mathrm{~L})$ & $25 \%(\mathrm{~L})$ & $5 \pm 1.0^{\mathrm{a}}$ & $2.32 \pm 0.01^{k}$ & $111.01 \pm 7.23^{b}$ \\
\hline & TMS-30572 & $603.84 \pm 5.76^{\mathrm{a}}$ & $2 \%(\mathrm{~L})$ & $40 \%(\mathrm{~L})$ & $1 \pm 1.0 \mathrm{~g}$ & $0.45 \pm 0.01^{\mathrm{n}}$ & $126.78 \pm 8.77^{b}$ \\
\hline & NR-84292 & $603.84 \pm 5.76^{\mathrm{a}}$ & $15 \%(\mathrm{~L})$ & $50 \%(\mathrm{~L})$ & $2 \pm 1.0 \mathrm{fg}$ & $1.28 \pm 0.01^{\mathrm{m}}$ & $124.54 \pm 8.27^{b}$ \\
\hline \multirow[t]{3}{*}{$150-300$} & NR-8082 & $588.40 \pm 4.0^{b}$ & $4 \%(\mathrm{~L})$ & $15 \%(\mathrm{~L})$ & $5 \pm 1.0^{\mathrm{a}}$ & $3.00 \pm 0.01^{\mathrm{i}}$ & $184.40 \pm 10.99 \mathrm{a}$ \\
\hline & TMS-30572 & $588.40 \pm 4.0^{\mathrm{b}}$ & $4 \%(\mathrm{~L})$ & $20 \%(\mathrm{~L})$ & $1 \pm 1.0 \mathrm{~g}$ & $1.42 \pm 0.01^{1}$ & $167.21 \pm 12.91^{\mathrm{ab}}$ \\
\hline & NR-84292 & $588.40 \pm 4.0^{b}$ & $12 \%(\mathrm{~L})$ & $31 \%(\mathrm{~L})$ & $3 \pm 1.0^{\text {effg }}$ & $2.47 \pm 0.01^{j}$ & $190.85 \pm 10.68^{\mathrm{a}}$ \\
\hline \multirow[t]{3}{*}{$300-450$} & NR-8082 & $557.29 \pm 1.49^{c}$ & $5 \%(\mathrm{~L})$ & $100 \%(\mathrm{~V})$ & $12 \pm 1.0^{b c}$ & $6.65 \pm 0.01^{\circ}$ & $194.31 \pm 10.90^{\mathrm{a}}$ \\
\hline & TMS-30572 & $557.29 \pm 1.49^{\circ}$ & $2 \%(\mathrm{~L})$ & $100 \%(\mathrm{~V})$ & $3 \pm 1.0^{\mathrm{efg}}$ & $3.67 \pm 0.01^{\mathrm{h}}$ & $202.63 \pm 15.11^{\mathrm{s}}$ \\
\hline & NR-84292 & $557.29 \pm 1.49^{\circ}$ & $12 \%(\mathrm{~L})$ & $100 \%(\mathrm{~V})$ & $8 \pm 1.0^{d}$ & $5.50 \pm 0.01^{\mathrm{e}}$ & $208.90 \pm 14.02^{\mathrm{a}}$ \\
\hline \multirow[t]{3}{*}{$450-600$} & NR-8082 & $448.91 \pm 5.37^{\mathrm{d}}$ & $6 \%(\mathrm{~L})$ & $100 \%(\mathrm{~V})$ & $14 \pm 1.0^{\mathrm{ab}}$ & $7.01 \pm 0.01^{b}$ & $202.54 \pm 9.55^{\mathrm{a}}$ \\
\hline & TMS-30572 & $448.91 \pm 5.37^{\mathrm{d}}$ & $8 \%(\mathrm{~L})$ & $100 \%(\mathrm{~V})$ & $4 \pm 1.0^{\text {ef }}$ & $4.08 \pm 0.01 \mathrm{~g}$ & $220.09 \pm 14.03^{\mathrm{a}}$ \\
\hline & NR-84292 & $448.91 \pm 5.37^{\mathrm{d}}$ & $12 \%(\mathrm{~L})$ & $100 \%(\mathrm{~V})$ & $8 \pm 1.0^{d}$ & $6.34 \pm 0.01^{d}$ & $206.78 \pm 12.67 \mathrm{~s}$ \\
\hline \multirow[t]{3}{*}{$1000-2000$} & NR-8082 & $428.83 \pm 0.79^{\mathrm{a}}$ & $2 \%(\mathrm{~L})$ & $100 \%(\mathrm{~V})$ & $16 \pm 1.0^{\mathrm{a}}$ & $8.33 \pm 0.01^{\mathrm{s}}$ & $194.37 \pm 9.08^{\mathrm{a}}$ \\
\hline & TMS-30572 & $428.83 \pm 0.79^{\mathrm{a}}$ & $2 \%(\mathrm{~L})$ & $100 \%(\mathrm{~V})$ & $4 \pm 1.0^{\text {ef }}$ & $4.58 \pm 0.01^{\mathrm{f}}$ & $197.31 \pm 11.48^{\mathrm{a}}$ \\
\hline & NR-84292 & $428.83 \pm 0.79^{\mathrm{e}}$ & $5 \%(\mathrm{~L})$ & $100 \%(\mathrm{~V})$ & $10 \pm 1.0^{\text {cd }}$ & $6.67 \pm 0.01^{\mathrm{c}}$ & $210.65 \pm 12.28^{\mathrm{a}}$ \\
\hline
\end{tabular}

Legends: $\%(\mathrm{~L})=$ plant loss

$\%(\mathrm{~V})=$ Plant viability

Mean of 3 determinations.

Within column, Mean \pm SEM with different superscripts are significantly different at the $\mathrm{P}<0.05$

--Insert Viability Table

Insert Quality of flare Table 
Effect Of Thermal Radiation On Viability Of Cassava Plant Population Cultivated Around Flare...

Table2.2: Rumuekpe flare quality measurement (Ringelmann)

\begin{tabular}{|c|c|c|c|c|c|c|c|c|c|c|c|c|c|}
\hline \multirow[t]{2}{*}{ DAYS } & \multicolumn{13}{|c|}{ MONTHS } \\
\hline & JUL & AUG & SEPT & OCT & NOV & DEC & JAN & FEB & MAR & APR & MAY & JUN & $\begin{array}{l}\text { DPR } \\
\text { LIMIT }\end{array}$ \\
\hline 1 & $X$ & 1 & 1 & 2 & 2 & 2 & 2 & 2 & 2 & 2 & 2 & 2 & 2 \\
\hline 2 & $X$ & 1 & 2 & 2 & 2 & 2 & 2 & 2 & 3 & 2 & 2 & 2 & 2 \\
\hline 3 & $X$ & 4 & 2 & 2 & 2 & 2 & $\mathrm{X}$ & 2 & 1 & 2 & 2 & 2 & 2 \\
\hline 4 & $X$ & 2 & 1 & 2 & 2 & 2 & $X$ & $X$ & $\mathrm{x}$ & 2 & 2 & 2 & 2 \\
\hline 5 & $X$ & 3 & 2 & 3 & 2 & 2 & 3 & 2 & $x$ & 2 & 2 & 2 & 2 \\
\hline 6 & $X$ & 3 & 2 & 3 & 3 & 2 & 2 & 2 & $x$ & 2 & 2 & 2 & 2 \\
\hline 7 & 3 & 3 & 2 & 2 & 2 & 2 & 3 & $\mathrm{X}$ & $\mathrm{x}$ & 3 & 2 & 2 & 2 \\
\hline 8 & 1 & 4 & 2 & 2 & 2 & 2 & 2 & $\mathrm{X}$ & $x$ & $\mathrm{X}$ & 2 & 2 & 2 \\
\hline 9 & 2 & 4 & 2 & 2 & 3 & 2 & 2 & $\mathrm{X}$ & $\mathrm{x}$ & $\mathrm{X}$ & 2 & 2 & 2 \\
\hline 10 & 1 & 4 & 2 & 2 & 2 & 2 & $\mathrm{x}$ & $\mathrm{X}$ & $\mathrm{x}$ & $\mathrm{X}$ & $X$ & 3 & 2 \\
\hline 11 & 1 & 2 & 2 & 1 & 2 & 2 & $\mathrm{x}$ & 1 & $\mathrm{x}$ & $\mathrm{X}$ & $X$ & 4 & 2 \\
\hline 12 & 1 & 2 & 2 & 2 & 3 & 2 & $x$ & 1 & $\mathrm{x}$ & $\mathrm{X}$ & $X$ & 2 & 2 \\
\hline 13 & 1 & 2 & 2 & 1 & 3 & 2 & $\mathrm{x}$ & 1 & $\mathrm{x}$ & $\mathrm{X}$ & $X$ & 4 & 2 \\
\hline 14 & 4 & 2 & 2 & $X$ & 2 & 2 & $\mathrm{x}$ & 1 & $\mathrm{x}$ & 2 & $X$ & 2 & 2 \\
\hline 15 & 4 & 3 & 2 & 1 & 2 & 2 & $x$ & 2 & $x$ & 2 & $X$ & 2 & 2 \\
\hline 16 & 4 & 4 & 2 & 1 & 2 & 2 & $\mathrm{x}$ & 1 & $\mathrm{x}$ & 2 & 2 & 2 & 2 \\
\hline 17 & 3 & 3 & 2 & 2 & 2 & 2 & $\mathrm{x}$ & 3 & $\mathrm{x}$ & 2 & 2 & 2 & 2 \\
\hline 18 & 2 & 3 & 2 & 1 & 1 & 2 & $\mathrm{x}$ & 3 & $\mathrm{x}$ & 2 & 2 & 2 & 2 \\
\hline 19 & 2 & 3 & 2 & 2 & 1 & 2 & $\mathrm{x}$ & 3 & $\mathrm{x}$ & 3 & 2 & $\mathrm{X}$ & 2 \\
\hline 20 & 2 & 4 & 3 & $X$ & 2 & 2 & $x$ & 2 & $x$ & 2 & 2 & $X$ & 2 \\
\hline 21 & 2 & 2 & 3 & $X$ & 2 & 2 & $\mathrm{x}$ & 3 & 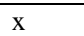 & 3 & 4 & $\mathrm{X}$ & 2 \\
\hline 22 & 2 & 2 & 3 & $X$ & 3 & 2 & $\mathrm{x}$ & 2 & 2 & 2 & 4 & $\mathrm{X}$ & 2 \\
\hline 23 & 3 & 2 & 2 & $X$ & 2 & 2 & $\mathrm{x}$ & 2 & 2 & $\mathrm{X}$ & 3 & $\mathrm{X}$ & 2 \\
\hline 24 & 3 & 2 & 2 & 2 & 1 & 2 & $\mathrm{x}$ & 2 & 2 & $X$ & 3 & $X$ & 2 \\
\hline 25 & 3 & 2 & 3 & 2 & 2 & 2 & $\mathrm{x}$ & 2 & 2 & $\mathrm{X}$ & 3 & $X$ & 2 \\
\hline 26 & 2 & $X$ & 4 & 2 & 2 & 2 & 2 & 2 & 3 & $X$ & 2 & $\mathrm{X}$ & 2 \\
\hline 27 & 2 & $\mathrm{X}$ & 2 & 2 & 3 & 2 & 2 & 3 & 2 & $\mathrm{X}$ & 2 & $\mathrm{X}$ & 2 \\
\hline 28 & 2 & $X$ & 2 & 2 & 3 & 2 & 3 & 1 & 3 & $X$ & 2 & $\mathrm{X}$ & 2 \\
\hline 29 & 2 & $\mathrm{X}$ & 3 & 2 & 2 & 2 & 2 & - & 3 & 2 & 2 & $\mathrm{X}$ & 2 \\
\hline 30 & 2 & $X$ & 2 & 2 & 2 & 2 & 2 & - & 2 & 2 & 2 & $X$ & 2 \\
\hline 31 & 3 & $\mathrm{X}$ & - & 2 & - & 2 & 2 & - & 2 & - & 2 & - & 2 \\
\hline
\end{tabular}

Legend : $\mathrm{X}$ : shut down of station

$\%$ Compliance $=77.98 \%$

$\%$ non-compliance $=22.02 \%$

Mean of 3 determinations

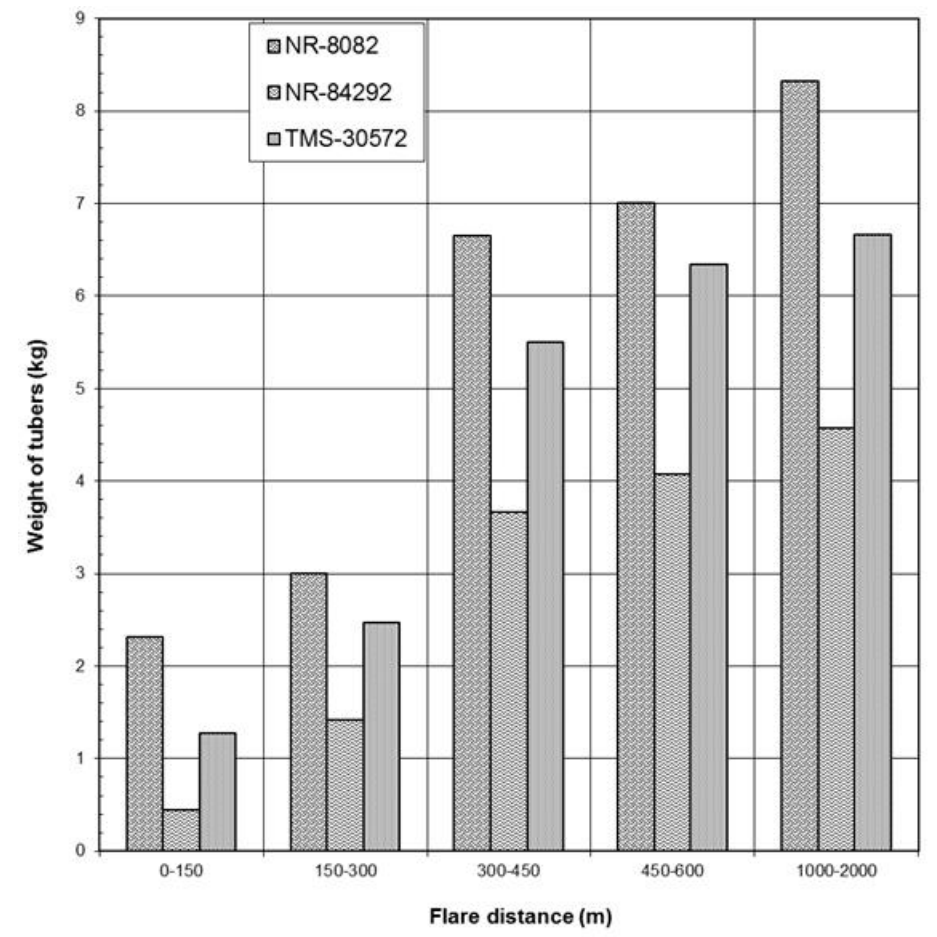

Fig. 1.0: Effect of flare distance and cassava cultivar on weight of tubers (Kg) 


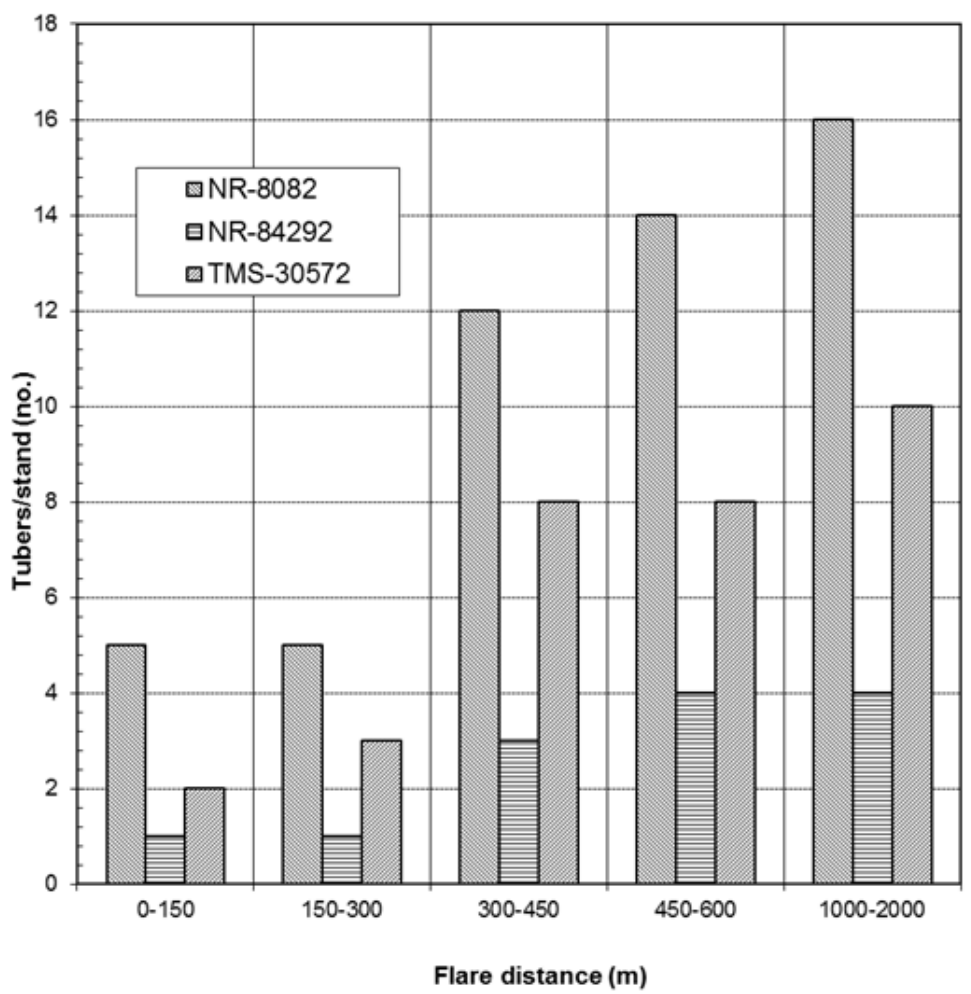

Fig. 2.0: Effect of flare distance and cassava cultivar on number of tubers per stand

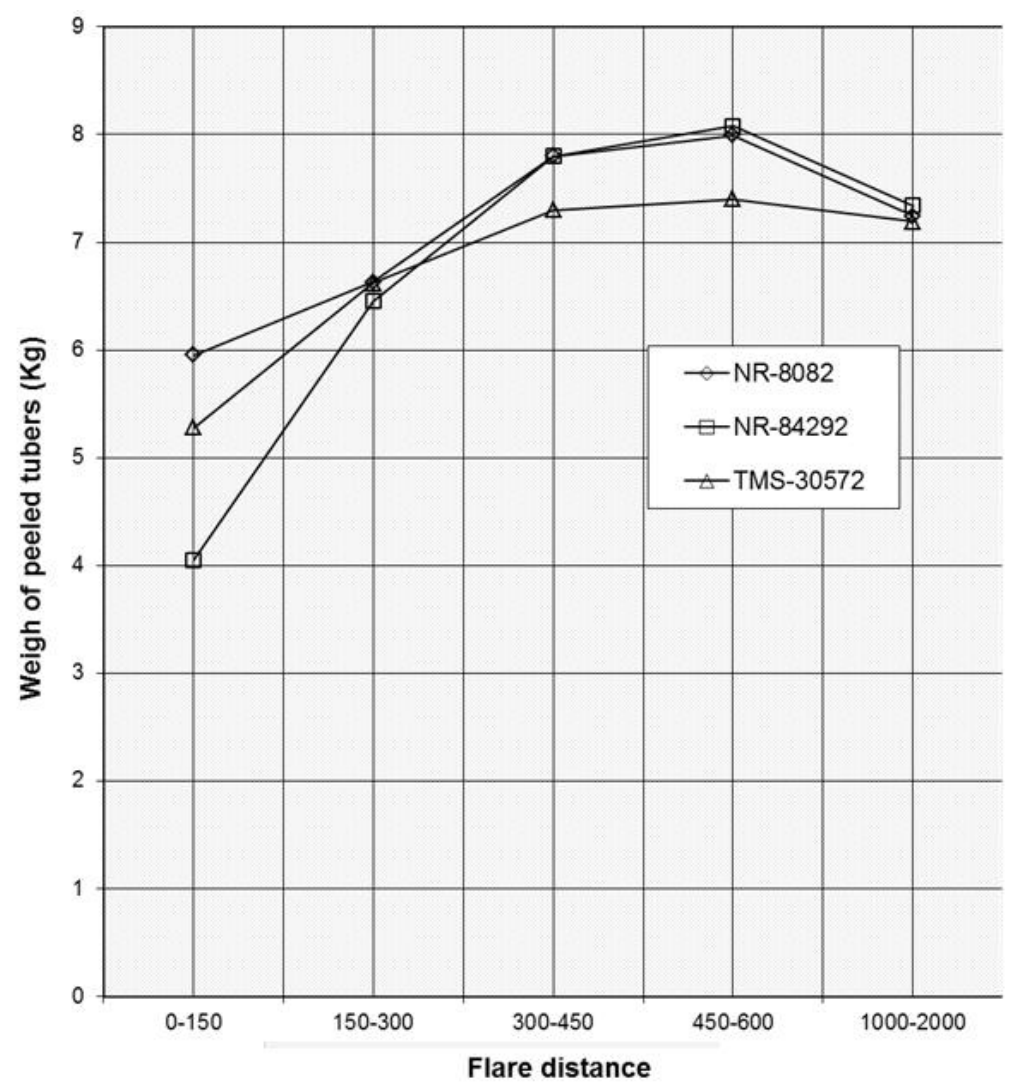

Fig.3.0: Effect of flare distance and cassava cultivar on the weight of peeled tubers $(\mathrm{Kg})$ 


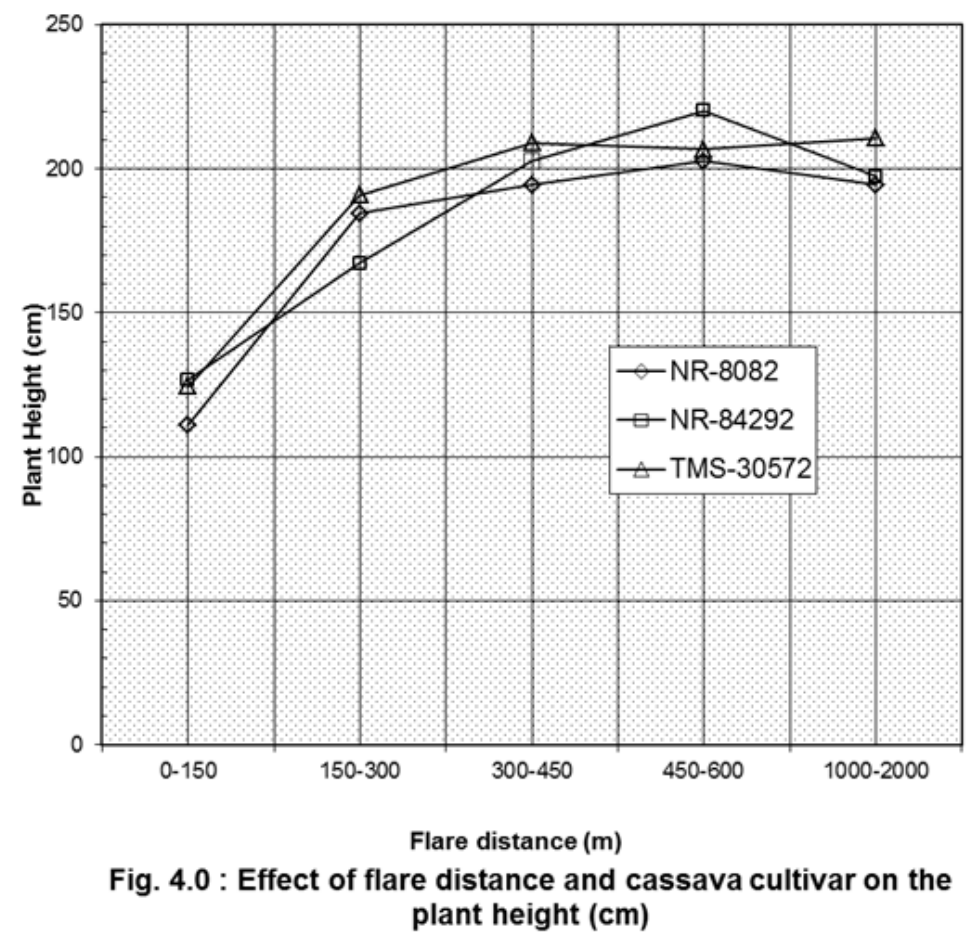

Table 2.1 showed a $2 \%$ and $15 \%$ and $4 \%$ and $12 \%$ losses for TMS 30572 and NR- 84292 at $0-150 \mathrm{~m}$ $\left(603.84 \pm 5.76 \mathrm{w} / \mathrm{m}^{2}\right)$ and $150-300 \mathrm{~m}\left(588.40 \pm 4.0 \mathrm{w} / \mathrm{m}^{2}\right)$ respectively. The control $1000-2000 \mathrm{~m}(428.83 \pm 0.79$ $\mathrm{w} / \mathrm{m}^{2}$ ) shows a population loss of 5\% for NR- 84292 and 2\% loss for NR- 8082 and TMS-30572 after one month of age. Also, the yield increases as the distance from the flare increases.

Effect of thermal radiation on population loss (viability) as presented in Table 2.1 shows a minimal effect on TMS 30572 plant population (viability) after one month of planting at the various flaring distances, as the losses could be attributed to number of factors such as the viability of the stem, soil temperature and heat from the flare. According to Ubani and Onyejekwe (2013),reported that in some cases, there is no vegetation in the areas surrounding the flare due partly to tremendous heat that is produced by the flare and acid nature of the soil. Gas flaring has been reported by many researchers to be a major cause of low agricultural productivity, fishing and hunting in the Niger Delta, thereby impoverishing the inhabitants (Morrison and Vincent (2013). The few scientific studies include those of Udoinyang (2005) and Akpabio (2006), on the impact of gas flaring on sweet potato and plantain yield, respectively. They showed that gas flaring reduced the production of these crops within $1 \mathrm{~km}$ of the flare sites.

At Ten (10) months of planting period, the effect of thermal radiation on viability was evident $(25 \%$ $50 \%$ ) population loss with severity in NR-84292 at $0-150 \mathrm{~m}$, while from $450-2000 \mathrm{~m}$ flaring distance, the plants showed 100 percentage viability. Flare quality measurement, using the Ringelmann chart was monitored for a period of one year according to Table. 2.2, which showed a compliance and non- compliance level of $77.98 \%$ and $22.02 \%$ respectively using the limits set by the department for petroleum resources (DPR).

The high degree of population loss associated with cultivar NR-84292 at 0-150m could be attributed to low tolerance of the cultivar to excessive thermal radiation. NR- 8082 and TMS-30572 could be said to have a high degree of tolerance to heat and other environmental stress, as shown in the $2 \%$ loss at $0-150 \mathrm{~m}$ and 1000 $2000 \mathrm{~m}$ flare distance respectively.

Also, the effect of thermal stress was severe on some of the cultivars at the early growth rate. This defect may be attributed to soil heat, which according to Hannah, (2001), Plant suffering from heat stress shut down basic growth functions and cannot draw sufficient water up into their leaves. Similarly, insufficient root activity as a consequence of high soil temperature would limit growth, because plants suffer from desiccation due to high transpiration and limited water uptake. After ten (10) months of planting period, the effect of thermal radiation on viability (plant population) was evident, (25-50\%) with severity in NR-84292 (50\%) losses. This agrees with the work of Gresshoff, (1993) that heat stress may cause results varying from wilt to discoloured leaves to severed desiccation and death. The effect of the high thermal energy from the flare is also pronounced on plant. In places where gas is flared grasses and trees do not grow within large radius (Ede and Johnson, 2000), owing to the high temperature of the immediate environment of the flare, crops planted do not do well. The effect of these on the economy and the life of the people within are felt seriously by the people living close to flare sites. 
NR-8082 had 25\% losses showing more tolerance at 0-150m-flare distance, $15-31 \%$ for NR-8082 and NR-84292 respectively at $150-300 \mathrm{~m}$. At $450-2000 \mathrm{~m}$, flare distance, the cultivars showed $100 \%$ viability and corresponding yield value of 12-16 tubers per 3 -Stand of NR-8082 cultivar and 8-10 tubers per 3-stand of TMS-30572 respectively. However, Ede and Johnson (2000) reported that the intensity of radiation is inversely proportional to the distance from the flare sites. That is at a distance greater than $50 \mathrm{~m}$ from the flare, the intensity of radiation is reduced.

The results revealed that NR-8082 had a high degree of heat tolerance when compared to the others $(25 \%$ and $15 \%)$ at $0-150 \mathrm{~m}$ and $150-300 \mathrm{~m}$ flare distance. NR-8082 was well-branched and formed canopy, therefore agreed with an earlier studies by Okezie and Okeke (1987) that the effect of flare on growth of maize crops was not very pronounced in relation to its effect on the yield. While loss in plant population of maize at $200 \mathrm{~m}$ distance ranged between $14 \%$ and $21 \%$, loss in yield of the same crop at the same distance from the flare was $100 \%$.

The results indicated that these observed effects of flare were not so much on the photosynthetic mechanism but rather on the reproductive and possibly food storage system. Figure 4.0 showed that for plant height the effect of flare was visible around $0-150 \mathrm{~m}, \mathrm{NR}-8082$ : $111.01 \pm 7.23 \mathrm{~cm}$, compared to NR-8082 $(202.50 \pm 9.55 \mathrm{~cm})$ at $450-600 \mathrm{~m}$ and NR 84292 at $450-600 \mathrm{~m}$ recorded $220.09 \pm 14.03 \mathrm{~cm}$. At $1000-2000 \mathrm{~m}$ the value of plant height ranged from $194.37 \pm 9.00 \mathrm{~cm}$ to $210.65 \pm 12.23 \mathrm{~cm}$ for NR-8082 and TMS-30572 respectively, However, this may apply at varying degrees to the cassava cultivar as TMS-30572 (40\% loss), a plant height $(124.54 \mathrm{~cm})$, and NR-84292 (50\% loss), plant height $(126.78 \mathrm{~cm})$, grows radiantly over NR-8082 ( $25 \%$ loss), plant height $(111.01 \mathrm{~cm})$ at $0-150 \mathrm{~m}$ flare distance. According to fig 2.0 . The number of tubers within 0-150m flare distance ranged from 1-5, while at the control, 10-16 tubers was recorded., Also, fig 1.0 shows an increasing weight values from $0.45 \pm 0.01$ to $8.33 \pm 0.01$ for TMS 30572 at $0-150 \mathrm{~m}$ and NR-8082 at $2 \mathrm{~km}$ respectively. This shows that NR-8082 is a good cultivar with respect to yield.

The quality of flared gas was monitored and compliance level of $77.79 \%$ and non-compliance level of $22.02 \%$ recorded for a period of one year. The $22.02 \%$ accounted for the generation and dispersal of particulates and incombustible materials (e.g soots) into the atmosphere, which could possibly affect growth of plants. It was known that these clouds of chemicals could trap heat radiated from the earth (that would have otherwise escaped rapidly into space), thus making flora, and fauna more vulnerable to heat waves and droughts (Egbuna, 1987). The $22.02 \%$ non-compliance of incombustible flare plum constitutes $20 \%$ light transmission through smoke and $80 \%$ smoke transmission through light (EGASPIN, 2002). Thus, pollution emissions (such as particulates and soots) are known to directly damage green foliage on which they settle, deteriorating air quality by causing breathing problems and lung illness and destroy laundry and other valuable property susceptible to dirt particles (Egbuna, 1987). These 22.02\% non-conformance could be due to carry over, operational upsets and station startup, while the $77.98 \%$ constitutes a clean flare of $80 \%$ light transmission through smoke and $20 \%$ smoke transmission through light which contributes to the overall thermal effect on the environment. The $77.98 \%$ agreed with the radiation level for a gas flare, which is also a function of flame temperature, gas flow rate and flare stack geometrical design (Egbuna, 1987).

Also, the quality of the flame could be improved by the use of boskel flare tip, liquid knockout pot/vessel and process optimization via gas/oil ratio configuration.

The non-compliance level of $22.08 \%$ does not conform to international standards/specification, since the flame must be luminous and bright. Thermal radiation is also known to affect the environment by baking the soil, destroying plants, soil organism and nutrients. Continuous ejection of excessive heat into the environment has increased the desert encroachment being noticed in some parts of the Niger Delta, since the water content of the soil can no longer support the rain forest. Climatic implications of excessive heat have been reported (Folland et al., 1995). There is an increased concern that gas flaring may be inadvertently changing the climate of the globe through the enhanced green-house effect by past and continuous emissions of carbon (iv) Oxide and other gasses which cause the temperature of the Earth's surface to increase - popularly termed the "Global Warming" (Watson, 1990).

\section{Conclusion}

The study further demonstrated that NR-8082 and TMS-30572 had a high degree of tolerance to heat and other environmental stresses, (5 and 2 tubers), with 1 tuber and 50\% plant population losses in NR-84292 at 0-150m flare distance, while the control had 100\% viability with 16 tubers for NR-8082 and 10 and 4 tubers for TMS-30572 and NR-84292 respectively.

It was observed that quality of gas flared monitored for a period of one year showed a compliance level of $77.79 \%$ and non-compliance level of $22.02 \%$ of light transmission through smoke and smoke transmission through light respectively.

Conclusively, plant and animal communities may also be directly affected by changes in their environment through variations in water, air and soil/sediment quality and through disturbance by noise, 
extraneous light and changes in vegetation cover. Such changes may directly affect the ecology: for example, habitat, food and nutrient supplies, breeding areas, migration routes, vulnerable to predators or changes in herbivore grazing patterns, which may then have a secondary effect on predators. Soil disturbance (thermal effect) may have an impact on ecological integrity, and may lead to indirect effects by upsetting nutrient balances and microbial activity in the soil. If not properly controlled, a potential long-term effect is loss of habitat, which affects both fauna and flora, and may induce changes in species composition and primary production cycles. It is important to consider how changes in the biological and physical environment also affect local people and indigenous populations

The few scientific studies include those of Udoinyang [2005] and Akpabio ( 2006), on the impact of gas flaring on sweet potato and plantain yield, respectively. They showed that gas flaring reduced the production of these crops within $1 \mathrm{~km}$ of the flare sites. Therefore, effect of thermal radiation on cassava cultiver vaiability and plant population is established.

\section{Reference}

[1]. Akpabio,Z.K.A (2006) "The Impacts of Gas Flaring on Microenvironment and Yield of Plantain in Rivers State, Nigeria," Environmental Perspectives, Vol. 10, No. 1, 2006, pp. 1-11.

[2]. Avwiri, G.O. and Ebeniro, J.O.(1994). Environmental impact of gas flaring at Obrikom Area of Rivers state. Nigeria Journal of physics vol 7: 72-75.

[3]. DTE-GEM. (2001). Geographic Information System- Geomatics Department, Shell Petroleum Development Company of Nigeria, Portharcourt.

[4]. Ede, P.N. and Johnson .G.A (2000). Energy relations of gas estimated from flare radiation in Nigeria.Int. J.Energy Res. Vol. 24: pp $1-7$

[5]. Egbuna D.O. (1987). The environmental hazards of the natural gas industry in petroleum industry and the Nigerian environment, Proceedings of 1987 Seminar. The Nigerian National Petroleum Corporation: Lagos, 346-350.

[6]. Environmental Guidelines and Standards for the Petroleum Industry in Nigeria (EGASPIN). (2002). Department of Petroleum Resources. Nigeria.

[7]. F.A.O (1994) Agroclimatological data for Africa. Vol. 1 (22) Food Agricultural Organisation of the United Nations, Rome.

[8]. Folland C.K., T.R. Karl and Kiya Vinnikoov (1995), Observed climatic variations and changes climatic changes (IPCC Scientific Assessment). Cambridge University Press, New York.

[9]. Gresshoff, P. M. (1993) Plant Response to the Environment. CRC press. Bola Raton, FL.

[10]. Hannah, M. (2001). Ornamental plants. Annual Reports and Research Review. The Ohio State University, Horticulture and crop science.

[11]. Idoniboye O. (1998) Hazard Management for Environmental Scientists. Lecture note.in the Institute of Geo science and Space Technology, RSUST, PH.

[12]. Isichei, A.O.and Sanford, M.W. (1970) The effects of waste Gas flare on the surrounding vegetation. In South Eastern Nigeria, Jour. Agric 2:221

[13]. Miller Reed ( 2015) Effect of Radiation on Plant—Submitted as a course work for PH241, Stanford University.

[14]. Morrison Ifeanyi Atuma and Vincent Nduka Ojeh (2013), Effect of Gas Flaring on Soil and Cassava Productivity in Ebedei, Ukwuani Local Government Area, Delta State, Nigeria , Journal of Environmental Protection, 2013, 4, 1054-1066 http://dx.doi.org/10.4236/jep.2013.410121 Published Online October 2013 (http://www.scirp.org/journal/jep)

[15]. Nature Conservation Report 1986.Shell Petroleum Developemt Company of Nigeria.Portharcourt

[16]. Ogoni Issue (1996). Shell Petroleum Development Company Official Position.

[17]. Okezie, D.U and A.O. Okeke,(1987) Flaring of Associated Gas in the oil Industry, Impact on Growth, Productivity and Yield of selected farm crops. Proceedings of the Petroleum Industry and the Nigerian Environment P 302-309.

[18]. Oluwatimilehin J.O. (1981). The Ecological Impact on the Oil Industry in the Niger Delta Area of Nigeria."M.Sc. Thesis, University of Ife Nigeria.

[19]. Perry, R.H. and Chilton C.H. (1973) Chemicl Engineers Handbook, $5^{\text {th }}$ ed., McGraw - Hill, New York - London.

[20]. RISADP (1991) Guide to Telfaria production. Agricultural Development Programme, Port Harcourt, Rivers State.

[21]. Ryan J.L ( 2012) Ioniing radiation. The Good, the Bad, and the Ugly. J, invest. Dermatol. 132.985

[22]. Sigalo, F.B (1997) Technical report on thermal radiation measurement at Olo Flow station and Rumuekpe metering station of Elf Nigeria Ltd.

[23]. Shell Petroleum Developement Company (SPDC). (2001). Challenges of Gas flares -Out in Nigeria. Briefing Notes

[24]. Ubani E.C. and Onyejekwe, I. M. (2013) Environmental impact analysis of gas flaring in the Niger Delta region of Nigeria. American J. of Scientific and industrial Research 4(2) 246-252

[25]. Udoinyang, G.U ( 2005) "The Effects of Gas Flaring on Sweet Potato Production in the Niger Delta, Nigeria," Journal of Ecosystem, Vol. 10, No. 1, pp. 77-86.

[26]. Wahua, A.T (1999), Advance Statistics and Field Experimentation. Crop Science Dept, Rivers State. University of Science and Technology, PortHarcourt

[27]. Watson, R.T., (1990) Greenhouse gases and climatic changes: Aerosols-Cambridge University Press, New York.

[28]. Yuan Z and Zeng L (1985) Popular science booklet series (meterology) p.56, published by China science and Technology press. 32 Baishiqiao Road, Beijing, China. 